\title{
DIMENSIONAL STABILIZATION OF WOOD TREATED WITH TALL OIL DISSOLVED IN DIFFERENT SOLVENTS
}

\author{
Ahmet Can $^{1, \diamond}$, Hüseyin Sivrikaya ${ }^{1}$
}

\begin{abstract}
Many water repellents, such as classic wood preservatives have the disadvantage of being harmful to the environment. Therefore, interest increased even eco-friendly, or of biodegradable material. Natural oils (tallow, linseed oil), appears to be capable of preventing the wood water uptake. However, the total amount of oil required to achieve a high penetration of the sapwood. The aim of this study was to investigate the water repellent efficiency of tall oil dissolved in different solvents. As solvents ethanol, methanol, acetone and tall oil water emulsions were used. Scots pine and Uludag fir sapwood samples were impregnated with tall oil formulations. For this purpose we used tall oil/solvents (W/W) at the concentrations of $10 \%$ and $20 \%$ respectively. Test samples cut into small sizes $(20 \times 20 \times 10 \pm$ $0,2 \mathrm{~mm}$ ) for water uptake and tangential swelling tests. The tests were carried out based on American Wood Protection Association (AWPA) standard E4 (2003).
\end{abstract}

Keywords: Abies nordmanniana, Pinus sylvestris, retention, swelling, water uptake.

\section{INTRODUCTION}

Wood and wood-based materials have been commonly used in the interior spaces for centuries and also constitute preferred multi-purpose materials for exterior applications. Unfortunately, some properties of wood such as moisture content, dimensional stability, biodegradability limited their use in service (Hon and Shiraishi 2001, Temiz et al. 2001, Kose et al. 2014).

The new, environmentally friendly and effective protection systems, is rEquationuired on wood protection in high humidity environments such as outdoor. Wood preservatives boosts dimensional stability and biological durability by using water repellent with low moisture content. Moisture content is a very effective way to protect the control timber. Environmentally friendly, biodegradable tall oil treatments are known for reducing the capillary water uptake (Tomak et al. 2011, Kose et al. 2014, Lahtela and Karki 2014).

Natural oils seem to be capable of decreasing water uptake and improving water repellence of wood. Palm oil, soy oil, slack wax, rape oil, soybean oil, linseed and hemp oil have recently been studied more intensely for water reppellent, as well as tall oil resins (Homan and Jorissen 2004, Schulte et al. 2004, Wang and Cooper 2005a, Spear et al. 2006, Tomak et al. 2010)

Tall oil is obtained as a by-product from pulp and paper industry based on kraft process of wood when pulping mainly coniferous trees, and is a mixture of fatty acids, rosin acids, and unsaponifiable substances (Koski 2008, Lahtela and Karki 2014).

In the previous study of tall oil is used above ground conditions showed potential as a wood

${ }^{1}$ Forest Industry Engineering, Faculty of Forest, Bartin University, Bartin, Turkey

"Corresponding author: acan@bartin.edu.tr

Received: 08.09.2015 Accepted: 07.02.2016 
preservative agent (Van Acker et al. 1999, Paajanen et al. 1999, Ritschkoff et al. 1999). Some researchers showed that tall oil alone was not able to fulfill the performance levels needed in order to be commercially developed as a wood protection system and they have suggested that tall oil should be used in conjunction with other biocides and very high retentions (Alfredsen and Flaete 2015). Temiz et al. (2008) compared boric acid and tall oil derivatives and noted that tall oil alone cannot give efficient protection against fungal decay.

\section{MATERIALS AND METHODS}

\section{Water repellent formulation and Impregnation process}

Kollicoat-IR, is a polyvinyl alcohol-polyethylene glycol graft copolymer that is freely soluble in water. The polymer consists of $75 \%$ polyvinyl alcohol units and $25 \%$ polyethylene glycol units. The product also contains approx. 0,3\% colloidal silica to improve its flow properties (URL-1 2015).

Tall oil dissolved in different solvents. As solvents ethanol, methanol, acetone and tall oil water emulsions were used. Emulsions were prepared with a mechanical dispenser for impregnation of the samples. First, the surface-active agent, which was 5 gr Kollicoat-IR for the oil in water emulsion, was mixed into the tall oil $(10 \mathrm{~g}-20 \mathrm{~g})$. Then, water $(80 \mathrm{~g}-90 \mathrm{~g})$ was added slowly to the mixture (Table 1). Scots pine (Pinus sylvestris) and Uludag fir (Abies nordmanniana subsp. Bornmulleriana) sapwood samples impregnated with tall oil formulations. For this purpose we used tall oil/solvents $(\mathrm{W} / \mathrm{W})$ concentrations of $10 \%$ and $20 \%$.

Table 1. Variation and short naming.

\begin{tabular}{|l|l|}
\hline Name & Content \\
\hline E10 & 90 gr Ethanol +10 gr Tall oil \\
\hline E20 & 80 gr Ethanol +20 gr Tall oil \\
\hline M10 & 90 gr Methanol +10 gr Tall oil \\
\hline M20 & 80 gr Methanol +20 gr Tall oil \\
\hline A10 & 90 gr Acetone +10 gr Tall oil \\
\hline A20 & 80 gr Acetone +20 gr Tall oil \\
\hline W10 & 90 gr Water +10 gr Tall oil +5 gr Kollicoat-IR \\
\hline W20 & 80 gr Water +20 gr Tall oil +5 gr Kollicoat-IR \\
\hline
\end{tabular}

Tall oil was obtained from Oyka Pulp and Paper Caycuma/Turkey. Wood samples were dried to absolute dry weight at temperature of $103{ }^{\circ} \mathrm{C}$ before impregnation. Impregnation were conducted in a small scale impregnation container using a vacuum of $650 \mathrm{~mm} / \mathrm{Hg}$ for $30 \mathrm{~min}$ followed by atmospheric pressure for $60 \mathrm{~min}$. Treated samples were left the outside of impregnation container for drying. The retentions for each treatment solution were calculated with Equation 1:

$$
R=\frac{G \times C}{100 \times V} \mathrm{~kg} / \mathrm{m}^{3}
$$

$\mathrm{G}$ is the difference between sample weight after impregnation and sample weight before impregnation $(\mathrm{kg}) ; \mathrm{C}$ is the concentration (\%); and $\mathrm{V}$ is the sample volume $\left(\mathrm{m}^{3}\right)$.

After impregnation, the treated samples were dried in an oven at $103{ }^{\circ} \mathrm{C}$ for $24 \mathrm{~h}$. The result of the modification was measured by weight percent gain (WPG), using the following equation 2:

$$
W P G(\%)=\frac{M_{2}-M_{1}}{M_{1}} \times 100
$$


where $\mathrm{M}_{2}$ is the weight after treatment, and $\mathrm{M}_{1}$ is the weight before treatment

\section{Water Absorption and Dimensional Stability Test}

For water absorption (WA) and dimensional stability test (DST), wood samples measuring $20 \times$ $20 \times 10 \mathrm{~mm}$ were prepared from Scots pine and Uludag fir sapwood. The samples were conditioned to $12 \%$ moisture content before water soaking. Treated and untreated samples were placed into beakers filled with distilled water at a temperature of $25,9 \pm 2{ }^{\circ} \mathrm{C}$. 6 replicates from each chemicals and concentrations were used. The water was replaced with fresh one after 30, 60, $120 \mathrm{~min}, 2,4,24,48,96$, hours. Experiments were carried out at the room temperature. Weight and dimensions of the samples were recorded. WA and DST were calculated according to equation 3 and equation 4 after each water replacement:

$$
\begin{gathered}
W A=\frac{W_{2}-W_{1}}{W_{1}} \times 100 \\
D S T=\frac{T_{2}-T_{1}}{T_{1}} \times 100
\end{gathered}
$$

Where $\mathrm{W}_{1}$ and $\mathrm{W}_{2}$ are the weights of the wood samples before and after test, $\mathrm{T}_{2}$ is the dimension at any given time during water soaked condition and $T_{1}$ is the initial tangential measure of the samples (AWPA E4, 2003). This method is designed to measure the dimensional stability of wood which has been pressure treated with a water repellent preservative.

\section{RESULTS AND DISCUSSION}

\section{Weight percent gain and retentions}

The impregnation results are presented in Table 2 by WPG and Retention.

Table 2. Weight percent gain and retentions of tall oil by wood samples in different solutions.

\begin{tabular}{|c|c|c|c|c|}
\hline \multirow{2}{*}{ Variations } & \multicolumn{2}{|c|}{ Scots pine (Pinus sylvestris) } & \multicolumn{2}{c|}{ Uludag fir (Abies bornmulleriana) } \\
\cline { 2 - 5 } & WPG $(\%)$ & Retention $\left(\mathrm{kg} / \mathrm{m}^{3}\right)$ & WPG $(\%)$ & Retention $\left(\mathrm{kg} / \mathrm{m}^{3}\right)$ \\
\hline E10 & $6,92(4,41)^{*}$ & $55,45(5,98)$ & $14,30(0,74)$ & $72,10(1,64)$ \\
\hline E20 & $15,66(1,71)$ & $105,60(10,41)$ & $28,34(1,58)$ & $147,75(3,9)$ \\
\hline M10 & $12,03(0,94)$ & $63,80(6,01)$ & $19,33(1,93)$ & $74,65(1,93)$ \\
\hline M20 & $20,40(1,92)$ & $125,20(10,16)$ & $31,08(2,86)$ & $150,30(9,77)$ \\
\hline A10 & $10,83(1,41)$ & $52,40(5,58)$ & $17,96(2,19)$ & $68,50(2,96)$ \\
\hline A20 & $19,70(2,16)$ & $102,20(15,06)$ & $34,32(7,24)$ & $137,40(4,9)$ \\
\hline W10 & $23,37(5,35)$ & $69,50(7,76)$ & $25,10(4,47)$ & $82,15(2,33)$ \\
\hline \multicolumn{7}{|l|}{ W20 } & $53,51(8,97)$ & $113,70(12,97)$ & $30,33(6,13)$ & $159,80(8,08)$ \\
\hline
\end{tabular}

The highest retention was $159 \mathrm{~kg} / \mathrm{m}^{3}$ in Uludag fir wood samples impregnated with W20. The lowest retention contents were seen in Ethanol solution. Scots pine retention rate was found lower than the Uludag fir wood. Many studies in the literature showed that the water in wood increase the absorbation rate of the oil compaunds to wood. This status relates with converting to fat/water solution of oil compounds absorbed by water in wood, with better absorpsion to wood (Tomak 2011).

The differences in retention between tall oil formulations may derive from viscosity differences. In emulsions, the addition of water decreases the viscosity of formulation. As shown in Table 2, the 
retention of fir samples impregnated with tall oil/water emulsions was slightly higher than other formulations. Due to the heterogeneous nature of the wood, the standard deviations of the retention were remarkably high in some formulations. The similar results were obtained by many studies in literature. In a study done, while consentration of oil compounds were rising in the wood impregnated with hemp oil diluted by acetone, retention rates increased. Retention rates of scots pine and beech were obtained as $447 \mathrm{~kg} / \mathrm{m}^{3}$ and $285 \mathrm{~kg} / \mathrm{m}^{3}$ for $75 \%$ fatty compounds and $145 \mathrm{~kg} / \mathrm{m}^{3}$ and $116 \mathrm{~kg} / \mathrm{m}^{3}$ for $25 \%$ oil compounds, respectively (Van Acker et al. 1999).

The higher retantion rate and WPG were obtained in impregnation with solution prepared by adding 5\% Kollicoat-IR. Kollicoat-IR is a copolymer grafted with polyvinyl alcohol-etilene glicol, therefore; The polymerization in the wood starts with the temperature applied after the impregnation. The variations in WPG can cause from high particle size in solution due to having to diffirent viscosity of fat/water solution. The surface agent importantly affects physical properties of the solition, and thus; the penetration and the dispersion of the impregnation to wood can change (Hyvönen et al. 2007b). Hyvönen et al. (2006) reported that the variations in the absorption changes according to air bubles and stability of the solution. It that the solution was can be variated penetration and dispersion into wood (Hyvönen et al. 2006, 2007b).

\section{Water Absorption and Dimensional Stability}

The results of water absorption tests of Scots pine and Uludag fir are listed in Figure 1-2 indicates relationship between water absorption and immersion time.

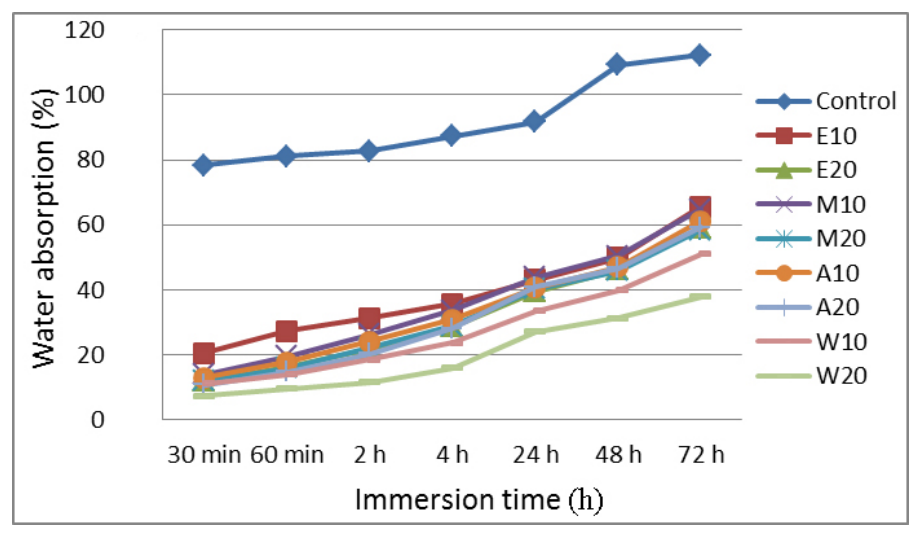

Figure 1. Water absorption results of Scots pine wood.

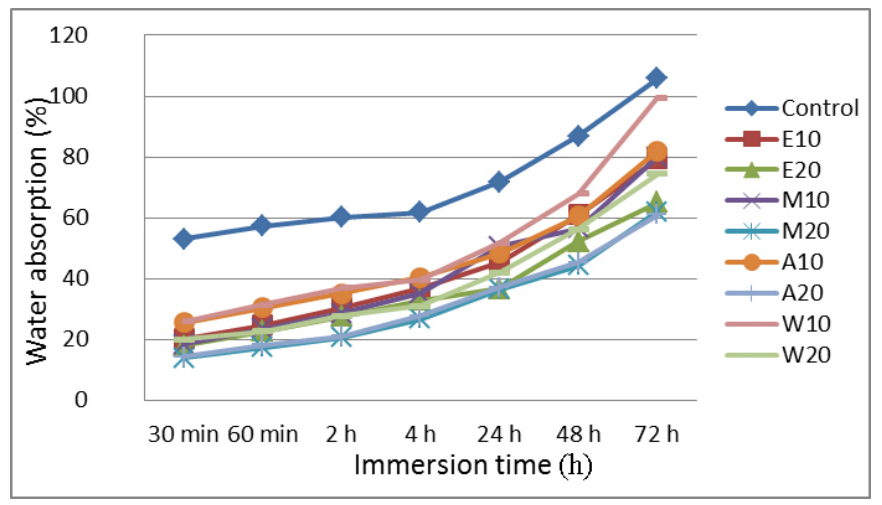

Figure 2. Water absorption results of Uludag fir wood. 
Water absorption values of the Uludag fir control samples showed an increase from 53,02\% (after $30 \mathrm{~min}$.) to $105,77 \%$ after 72 hours of exposure in water. With increasing chemical concentrations, water absorption values decreased, but values were close to each other. It is obvious in Figure 2 that samples treated with water emulsions (W10-W20) showed the highest water absorption after 48 hours and after 72 hours reached to $99,54 \%$. Statistical water is located in the same group with control.

Some researchers have tried different oils for water repellents. Bazyar et al. (2010) treated Poplar samples with linseed oil, and then they found the $75 \%$ less water absorption compare to control. Temiz et al. (2008) found the lower water absorption value (50-55\%) in samples treated with PTEOS (phenyltriethoxysilane) after 2 weeks. Wang and Cooper (2005a,b) treated Spruce samples and then they found the lower water absorption value (20-40\%) in samples treated with Soybean oil, palm oil and waxes. In another study, linseed oil, tung oil, coconut oil, and three diffirent tall oil were used. According to the results, $66-89 \%$ for water repellency and $20 \%$ for water uptake were provided by Van Eckeveld et al. (2001).

The results of tangential swelling tests of Scots pine and Uludag fir are listed in Figure 3-4 indicates relationship between tangential swelling and immersion time.

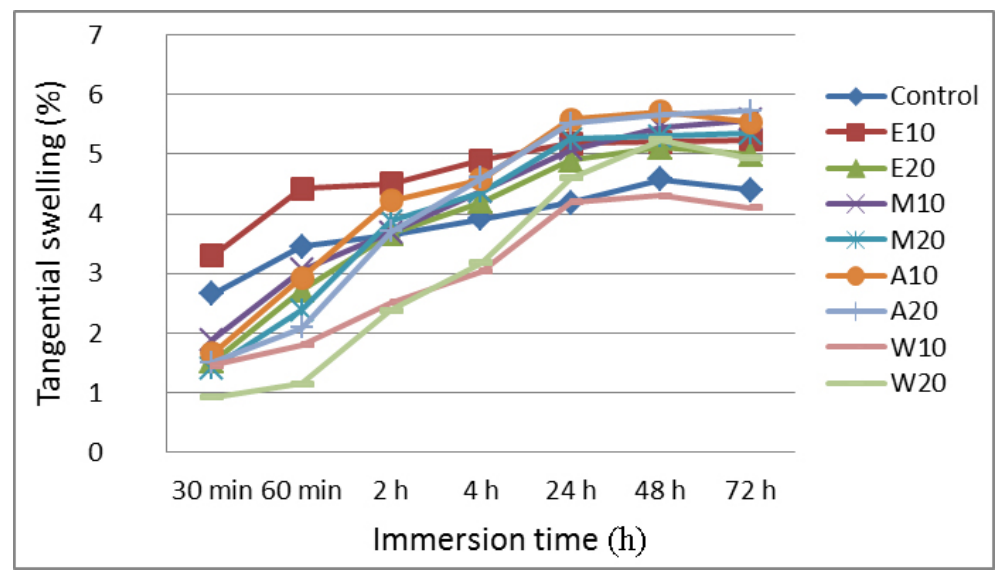

Figure 3. Tangential swelling Scots pine wood.

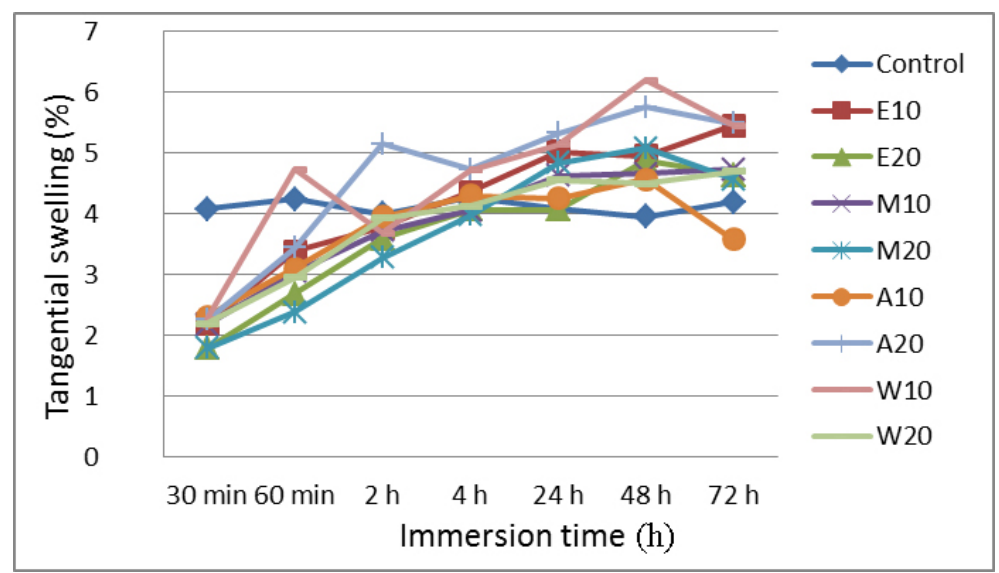

Figure 4. Tangential swelling Uludag fir wood. 
The Scots pine treated with water emulsions (W10-W20) statistically showed less tangential swelling than the samples treated with others variations (Table 3). According to results, the highest tangential swelling value was obtained with A20 while the lowest swelling value was obtained with W10. Further immersion durations exhibited more tangential swelling for some formulations. But there was no significant difference with control samples for both Scots pine and Uludag fir. In a similar study performed with water glass and tall oil treatments negatively affected thickness swelling compared to control samples (Lahtela and Karki 2014). In another study, when use of oil tangential swelling was reduce. This reduction increased with further increase in temperature (Bal 2015).

Table 3. Water absorption (\%) and tangential swelling (\%). Results after 72 hours.

\begin{tabular}{|l|c|c|c|c|}
\hline & \multicolumn{2}{|c|}{ Scots pine (Pinus sylvestris) } & \multicolumn{2}{c|}{ Uludag fir (Abies bornmulleriana) } \\
\hline & $\begin{array}{c}\text { Water Absorption } \\
(\text { WA) }\end{array}$ & $\begin{array}{c}\text { Tangential swelling } \\
(\text { TS })\end{array}$ & $\begin{array}{c}\text { Water Absorption } \\
(\text { WA) }\end{array}$ & $\begin{array}{c}\text { Tangential swelling } \\
(\mathrm{TS})\end{array}$ \\
\hline Control & $112,23^{\mathrm{a}}(0,11)^{*}$ & $4,40^{\mathrm{h}}(0,20)$ & $105,77^{\mathrm{a}}(0,12)$ & $4,20^{\mathrm{d}}(0,31)$ \\
\hline E10 & $65,56^{\mathrm{b}}(0,22)$ & $5,25^{\mathrm{e}}(0,45)$ & $79,25^{\mathrm{b}}(0,10)$ & $5,46^{\mathrm{d}}(0,19)$ \\
\hline E20 & $59,13^{\mathrm{c}}(0,07)$ & $4,99^{\mathrm{f}}(0,40)$ & $64,96^{\mathrm{dc}}(0,16)$ & $4,64^{\mathrm{ba}}(0,14)$ \\
\hline M10 & $64,84^{\mathrm{b}}(0,17)$ & $5,58^{\mathrm{b}}(0,52)$ & $79,97^{\mathrm{b}}(0,11)$ & $4,73^{\mathrm{dcb}}(0,10)$ \\
\hline M20 & $58,43^{\mathrm{c}}(0,11)$ & $5,35^{\mathrm{d}}(0,60)$ & $62,04^{\mathrm{d}}(0,12)$ & $4,57^{\mathrm{dcb}}(0,51)$ \\
\hline A10 & $61,15^{\mathrm{cb}}(0,12)$ & $5,54^{\mathrm{c}}(0,51)$ & $82,05^{\mathrm{b}}(0,07)$ & $3,59^{\mathrm{dc}}(0,13)$ \\
\hline A20 & $59,30^{\mathrm{c}}(0,19)$ & $5,73^{\mathrm{a}}(0,61)$ & $60,90^{\mathrm{d}}(0,17)$ & $5,48^{\mathrm{e}}(0,25)$ \\
\hline W10 & $51,12^{\mathrm{d}}(0,13)$ & $4,10^{\mathrm{1}}(0,56)$ & $99,54^{\mathrm{a}}(0,31)$ & $5,46^{\mathrm{cba}}(0,35)$ \\
\hline W20 & $37,87^{\mathrm{c}}(0,22)$ & $4,94^{\mathrm{g}}(0,67)$ & $74,47^{\mathrm{cb}}(0,28)$ & $4,69^{\mathrm{a}}(0,45)$ \\
\hline
\end{tabular}

*Values in parenthesis are standard deviation.

${ }^{\text {a }}$ Similar letter indicates no statistical significance.

\section{CONCLUSIONS}

Tall oil treatments reduced the water uptake of Scots pine and Uludag fir sapwood. Tall oil treatments (with ethanol, methanol, acetone and oil-in-water) showed almost equal efficiencies for each formulation; even if the retentions were considerably different. Very complicated results were obtained in tangential swelling. This process revealed more effective results with Scots pine samples on water uptake while it was seen more effective in Uludag fir samples on tangential expansion. Statisticaly, W20 in Scots pine and A20 in Uludag fir are effective has been demonstrated. Further experiments should be done effects of tall oil dissolved in different solvents on physical, biologycal and mechanical properties of wood. 


\section{REFERENCES}

Alfredsen, G.; Flaete, P.O. 2015. Tall oil performance after a decade of field exposure. Annual meeting. The International Research Group on Wood Protection. Chile. May, 2015. IRG/WP 15-30672.

AWPA E4. 2003. Standard Method of Testing Water Repellency of Pressure Treated Wood.

Bal, C. 2015. Physical properties of beech wood thermally modified in hot oil and in hot air at various temperatures. Maderas-Cienc Tecnol 17(4):789-798.

Bazyar, B.; Parsapajouh, D.; Khademiesalam, H. 2010. An Investigation on Some Physical Properties of Oil Heat Treated Poplar Wood. 41. IRG Annual Meeting, IRG-WP 10-40509. France. May, 2010 573.

Hon, D.N.S.; Shiraishi, N. 2001. Wood and Cellulosic Chemistry. Marcel Dekker: New York, p

Homan, W.J.; Jorissen, A.J.M. 2004. Wood modification developments. Heron 49(4).

Hyvönen, A.; Piltonen, P.; Niinimaki, J. 2006. Tall oil/water - emulsions as water repellents for Scots pine sapwood. Holz als Roh- und Werkstoff 64: 68-73

Hyvönen, A.; Nelo, M.; Piltonen, P.; Niinimäki, J. 2007b. Using the Emulsion Technique and an Iron Catalyst to Enhance the Wood Protection Properties of Tall Oil. Holz als Roh-und Werkstoff 65(3).247-249.

Kose, G.; Temiz, A.; Demirel, S.; Özkan, O.E. 2014. Using Commercial Water Repellent Chemicals on Wood Protection. IRG Annual Meeting, The International Research Group on Wood Protection. USA. May, 2014. IRG/WP 14-30656.

Koski, A. 2008. Applicability of crude tall oil for wood protection. Dissertation. University of Oulu.

Lahtela, V.; Karki, T. 2014. Improving the UV and water-resistance properties of Scots pine (Pinus sylvestris) with impregnation modifiers. Eur J Wood Prod 72:445-452

Paajanen, L.; Koskela, K.; Viitaniemi, P. 1999. Treatment of wood with a mixture of tall oil and maleic anhydride. VTT Julkaisuja, 836.

Ritschkoff, A.C.; Ratto, M.; Nurmi, A.; Kokko, H.; Rapp, A.; Militz, H.; 1999. Effect of some resin treatments on fungal degradation reactions. IRG Annual Meeting, The International Research Group on Wood Preservation. Germany. June, 1999. IRG/WP 99-10318

Schulte, Y.; Donath, S.; Krause, A.; Militz, H. 2004. Evaluation of outdoor weathering performance of modified wood. IRG Annual Meeting. International Research Group on Wood Preservation. Slovenia. June, 2004. IRG/WP 04-20296

Spear, M.J.; Hill, C.A.S.; Curling, S.F.; Jones, D.; Hale, M.D. 2006. Assessment of the envelope effect of three hot oil treatments: Resistance to decay by Coniophora puteana and Postia placenta. IRG Annual meeting. International Research Group on Wood Preservation. Norway. June, 2006. IRG/WP 06-40344.

Temiz, A.; Yildiz, U.C.; Gezer, E.G. 2001. Physical and mechanical properties of wood-polymer composites prepared from alder wood (Alnus glutinosa (1.) gaertn. subsp. barbata (c.a.mey.) yalt). International Research Group on Wood Preservation, Proceedings IRG Annual Meeting, Japan. May, 2001. IRG/ WP 01-40201, 
Temiz, A.; Alfredsen, G.; Eikene, M.; Terziev, N. 2008. Decay resistance of wood treated with boric acid and tall oil derivates. Bioresource Technology 99: 2102-2106.

Tomak, E.D.; Yildiz, U.C.; Can, A. 2010. Treatment of Scots pine wood with oil in water and water in oil emulsion systems: Effects on boron leaching and water absorption. IRG Annual meeting. International Research Group on Wood Preservation. France, May 2010. IRG/WP 10-30535

Tomak, E.D. 2011. The effect of oil heat treatment and emulsion techniques on decreasing the leachability of boron in wood. Karadeniz Technical University The Graduate School of Natural and Applied Sciences, Forest Industrial Engineering Graduate Program, Trabzon.

Tomak, E.D.; Viitanen, H.; Yildiz, U.C.; Hughes, M. 2011. The combined effects of boron and oil heat treatment on the properties of beech and Scots pine wood. Part 2: Water absorption, compression strength, color changes, and decay resistance. Journal of Material Science 46: 608-615.

Van Acker, J.; Nurmi, A.; Gray, S.; Militz, H.; Hill, C.; Kokko, H.; Rapp, A. 1999. Decay resistance of resin treated wood. IRG Annual meeting. The International Research Group on Wood Preservation, Germany. IRG/WP 99-30206.

Van Eckeveld, A.; Homan, W.J.; Militz, H. 2001. Increasing the Water Repellency of Scots Pine Sapwood by Impregnation with Undiluted Linseed Oil, Wood Oil, Coccos Oil and Tall Oil. Holzforschung und Holzverwertung 6: 113-115.

Wang, J.Y.; Cooper, P. 2005a. Effect of oil type, temperature and time on moisture properties of hot oil-treated wood. Holz als Roh- und Werkstoff 63: 417-422

Wang, J.; Cooper, P. 2005b. Properties of Hot Oil Treated Wood and the Possible Chemical Reactions Between Wood and Soybean Oil During Heat Treatment. 36. IRG Annual Meeting, India. April, 2005. IRG-WP 05-40304. 